\title{
Tempo paisagem
}

\section{2}

Entre ruínas e paisagens a vida persiste. São as marcas do tempo que deixam brechas pra vermos a relação entre o passado, o presente e o futuro. É como se o tempo se materializasse numa janela. Portal para vermos o que é a matéria da nossa história. Somos a vida que pulsa, a ruína e a paisagem.

Esta imagem foi feita na antiga estação ferroviária de Santa Maria, RS.

Sônia Vill 

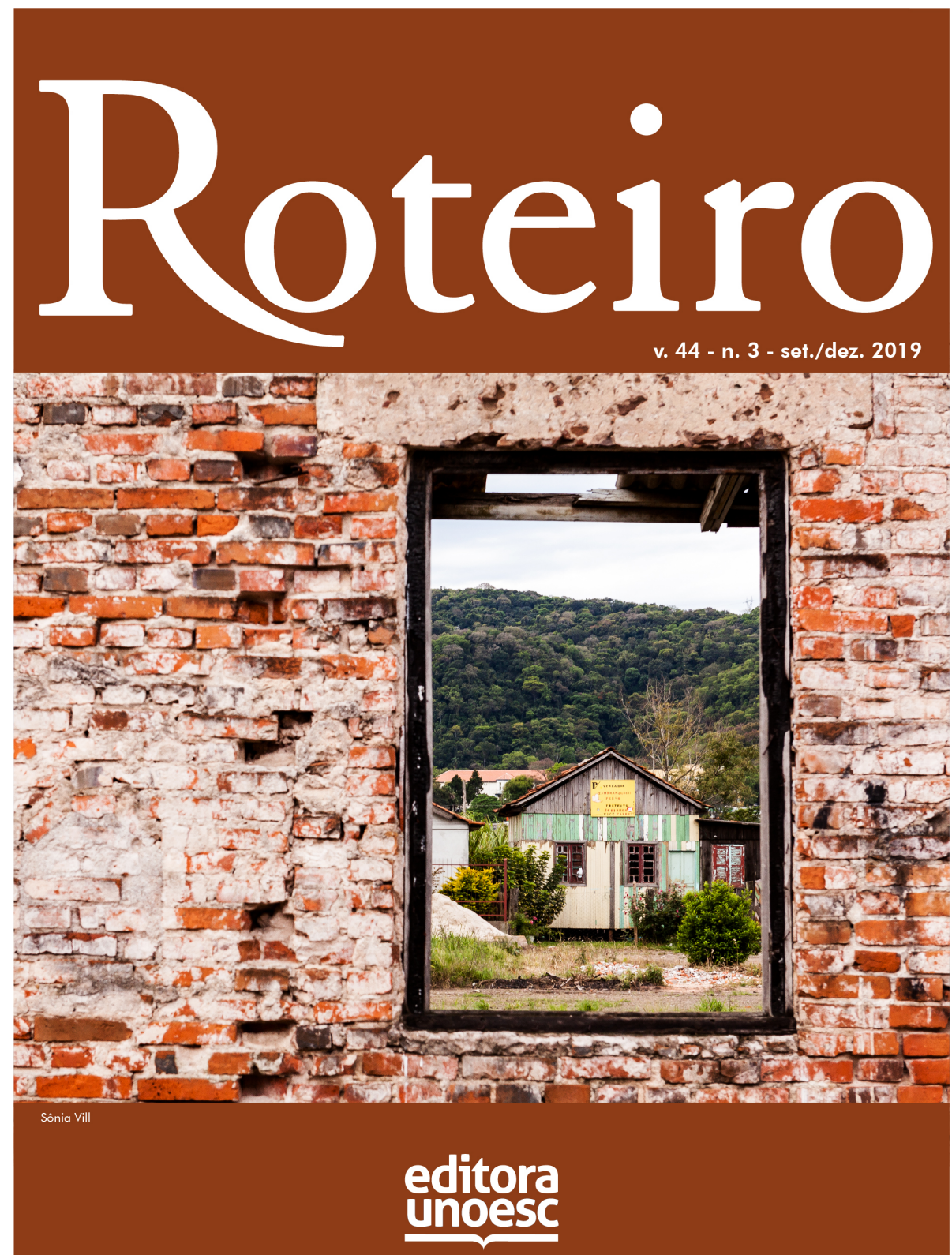

DOI desta edição: htłps://doi.org/10.18593/r.v44i3 